\title{
Effect of Serum from Normal and Cystic Fibrosis Subjects on Mucin Secretion from Dispersed Rat Submandibular Cells
}

\author{
DAVID O. QUISSELL, ${ }^{(17,18)}$ RUTH J. MCDONALD, ${ }^{(19)}$ KATHERINE A. BARZEN, AND \\ LYNN M. DEISHER \\ Department of Biochemistry, Biophysics and Genetics and Department of Pediatrics, University of Colorado \\ School of Medicine, Denver, Colorado, USA
}

\begin{abstract}
Summary
The action of serum from cystic fibrosis patients, obligatory heterozygotes, siblings, and normal patients on mucin secretion from dispersed rat submandibular cells was investigated in an attempt to demonstrate the existence of cystic fibrosis specific factors affecting mucin secretion. No effects specific to cystic fibrosis serum were demonstrated using the following parameters for evaluation: (1) maximal stimulation of mucin release by a $\beta$ adrenergic agonist, (-)-isoproterenol; (2) basal release (unstimulated secretion) of mucin material; and (3) the dose-response relationship for mucin release after $\beta$-adrenergic receptor stimulation. No differences were observed in mucin secretion using media concentrations of serum of up to $10 \%$. From these data, we conclude that serum from individuals with cystic fibrosis does not contain bioactive factors at concentrations that specifically alter mucin secretion in rat submandibular acinar cells.
\end{abstract}

\section{Abbreviations}

CF, cystic fibrosis

dpm, disintegrations per minute

TCA-PTA, $10 \%$ trichloroacetic acid- $0.5 \%$ phosphotungstic acid $(w / v)$ containing $4 \mathrm{mM}$ D-glucosamine

$\mathrm{CF}$ is the most common lethal genetic disease in the Caucasian population. The clinical manifestations of the disease include obstructive pulmonary disease, increased sweat electrolyte content, and pancreatic insufficiency. Despite its common occurrence, one in 2000 live births, the molecular basis of CF is not known.

It was almost 15 years ago when the first report was published, which implicated a bioactive "factor" in the etiology of CF (15). Since then extensive research efforts have been directed toward the identification of the bioactive factors and considerable discussion has been directed toward understanding the involvement of these CF factors in the pathogenesis of CF. Despite the time and research efforts devoted to this particular area of $C F$ research, bioactive factors are steeped in controversy and their relevance to CF remains obscure.

The fundamental existence of an apparent exocrine gland dysfunction in CF and the possible existence of bioactive serum factors, which could conceivably cause exocrine dysfunction, led us to investigate the effects of $\mathrm{CF}$ serum on exocrine secretory function. Specifically, we evaluated the effects of CF serum on cation transport (14) and on mucin secretion from dispersed rat submandibular cells.

The cell dispersion system was chosen because: $(I)$ it is an appropriate model involving a mammalian mucin-secreting exocrine gland, which is pathologically altered in CF; (2) the use of a dispersed cell system obviates many of the technical problems associated with in vivo perfusion and in vitro gland slices or tissue explants; and (3) the physiologic and pharmacologic parameters of the secretory response of the dispersed cells have been identified and characterized (9-12).

\section{METHODS}

Subjects. Blood samples were obtained from patients with CF, ages $8-25$ years, who had clinical, radiologic, and sweat electrolyte levels classical for $\mathrm{CF}$. The serum from a total of $14 \mathrm{CF}$ patients, 12 control subjects, seven obligatory heterozygote and four siblings was tested. CF serum samples were from seven males and seven females having Taussig scores (13) ranging from $71-100$ with a mean value of 87 . Thirteen of the CF subjects were on pancreatic enzyme supplementation, nine CF subjects were on chronic theophylline treatment, four were on vitamin supplementation, four were taking $\beta_{2}$-agonists, two were on chronic antibiotic treatment, and one CF subject was on phenobarbital. Six of the CF subjects were clear of chronic pulmonary infection, six had moderate chronic pulmonary infection, and two had severe lung infection.

The 12 normal subjects, ages 12-26 years and sex-matched, were healthy individuals taking no medication and who had no personal or family history of CF. The seven obligatory heterozygotes were the parents of the CF subjects in this study.

Preparation of dispersed cells. The method of rat submandibular cell preparation has recently been published $(9,12)$. Briefly, male Sprague-Dawley rats, weighing 175-200 g (42-48-daysold), were housed under controlled environmental conditions and allowed food and water ad libitum. All animals were sacrificed between 8 and 10 A.M. After being anesthetized by an intraperitoneal injection of pentobarbital sodium and subsequent exsanguination via the abdominal aorta, the submandibularsublingual complex was removed through a ventral midline incision in the neck. The submandibular glands were separated from the sublingual glands, minced, suspended in dispersion

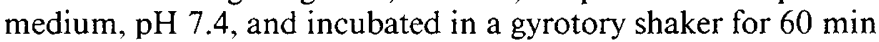
at $37^{\circ} \mathrm{C}$ under an atmosphere of $95 \% \mathrm{O}_{2}-5 \% \mathrm{CO}_{2}$. The dispersion medium consisted of a calcium-free modified Hanks salt solution supplemented with BME-amino acids (GIBCO) (9), which contained $50-75 \mathrm{U} / \mathrm{ml}$ chromatographically purified collagenase and $1.0 \mathrm{mg} / \mathrm{ml}$ hyaluronidase. After dispersion the cells were washed, filtered, washed, resuspended in final incubation medium containing BME-amino acids (GIBCO), and incubated for $30 \mathrm{~min}$ and washed again before any experimental manipulation. The $\mathrm{pH}$ of the cell suspension was adjusted to 7.4 with $0.1 \mathrm{M} \mathrm{Na}_{3} \mathrm{PO}_{4}$ and the osmolality of all solutions was adjusted to $300 \mathrm{mosM}$ with $1 \mathrm{M} \mathrm{NaCl}$. Ascorbic acid $(0.1 \mathrm{mM})$ was added every $20 \mathrm{~min}$ to the medium during stimulation to inhibit the nonenzymatic oxidation of $(-)$-isoproterenol. 
Preparation of serum samples. Blood was collected by venipuncture using a plastic syringe and immediately transferred to a polypropylene tube. Specimens were incubated at $37^{\circ} \mathrm{C}$ until contraction of the clot (approximately $30 \mathrm{~min}$ ). After centrifugation at $10,500 \times g$ for $3 \mathrm{~min}$, the serum was removed with polypropylene or glass pipettes and transferred to plastic tubes. Samples were stored at $-70^{\circ} \mathrm{C}$. Frozen specimens were rapidly thawed at $37^{\circ} \mathrm{C}$ (within $5 \mathrm{~min}$ ) just before experimental evaluation and kept on ice. Each specimen was thawed only once and the remaining serum was discarded after use.

Release of $\left[{ }^{14} \mathrm{CJ}\right.$-labeled trichloroacetic acid and phosphotungstic acid precipitable material. After completion of the cell isolation procedure, the submandibular cells were incubated for 1 $\mathrm{h}$ in the presence of $1 \mu \mathrm{Ci} / \mathrm{ml}$ of $\mathrm{D}-\left[1-{ }^{14} \mathrm{C}\right]$ glucosamine. The cells were washed three times in incubation medium, which was supplemented with $1 \mathrm{mM} \mathrm{D-(+)-glucosamine,} \mathrm{and} \mathrm{incubated} \mathrm{for}$ another hour before experimental manipulation. They were then washed three times and resuspended in incubation medium having a cell-to-medium volume of $2.5-5 \%$.

Two hundred microliters of the cell suspension were removed, and the high-molecular-weight mucins were precipitated by the addition of $2 \mathrm{ml}$ of TCA-PTA. After the addition of agonist or serum, or both, samples were removed at various time intervals, the cells were centrifuged, and the supernatant was removed and analyzed for the amount of TCA-PTA precipitable $\left[{ }^{14} \mathrm{C}\right] \mathrm{dpm}$. The precipitates were washed twice with the TCA-PTA solution and then hydrolyzed in $1 \mathrm{ml}$ of $88 \%$ formic acid. The amount of precipitated $\left[{ }^{14} \mathrm{C}\right]$ was determined via liquid scintillation counting in which ACS, an aqueous counting scintillant from Amersham, was used. Samples were counted in a Beckman 100/ LS liquid scintillation spectrophotometer and were corrected for quenching by use of the automatic external standard technique. The counting efficiency was approximately $80 \%$. The amount of precipitable $\mathrm{dpm}$ released was normalized from experiment to experiment by expressing the amount released as a percentage of the total cellular precipitable $\left[{ }^{14} \mathrm{C}\right] \mathrm{dpm}$ present at the beginning of each experiment.

Statistical analysis. The biologic variation in the rate of mucin release was far greater than the differences between the experimental groups. When statistical comparisons were made, the Student's paired $t$ test was used and a $P$ value less than 0.05 was considered significant.

\section{RESULTS}

Because it has been reported that only very small concentrations of serum $(0.5 \%)$ are required in bioassay procedures $(1-7$,
15) for the detection of the CF serum factors, we first evaluated the effect of serum on $\beta$-adrenergic receptor mediated mucin release. Using $10 \mu \mathrm{M}(-)$-isoproterenol, we were unable to observe any significant effects of serum on the secretory response of the isolated rat submandibular cells using serum concentrations of up to $10 \%$, a 50 -fold higher concentration than that reported by others (Fig. 1). The apparent slight decrease in total radiolabel release observed in the presence of serum was not statistically significant and serum levels above $10 \%$ were toxic to the isolated submandibular cells.

The effect of serum on mucin secretion was further evaluated by determining the extent of mucin release in the presence and absence of $\beta$-adrenergic receptor mediated stimulation. Besides evaluating serum obtained from CF patients and age- and sexmatched controls, we also evaluated serum from obligatory heterozygotes and siblings. The results of these studies are presented in Figure 2 . In the absence of $\beta$-adrenergic stimulation, the presence of serum $(5 \%)$ in the incubation medium had a marginally significant effect on the release of radiolabeled mucin material over the $40-\mathrm{min}$ incubation period $(P=0.05)$. But no experimental differences were observed between any of the groups after stimulation with $10 \mu \mathrm{M}(-)$-isoproterenol. As previously demonstrated in Figure 1 , the presence or absence of serum $(5 \%)$ had no discernible influence on the extent of the mucin secretory response after stimulation.

Because of the lack of effect of normal serum and a failure to observe any differential effect of $\mathrm{CF}$ serum on total $\left[{ }^{14} \mathrm{C}\right] \mathrm{glyco}$ protein release, a study was performed to determine if serum-in particular CF serum-potentiates or inhibits $\beta$-adrenergic stimulated mucin release during submaximal stimulation. A fixed concentration of serum (5\%) was added to the dispersed cell suspension just before the addition of different concentrations of a $\beta$-adrenergic agonist, (-)-isoproterenol, and the extent of radiolabeled glycoprotein release was evaluated after $40 \mathrm{~min}$ of incubation. Control studies also included evaluating the dose-response relationship of the isolated submandibular cells to $(-)$ isoproterenol stimulation in the absence of serum. As shown in Figure 3, the dose-response relationship for all three groups was essentially identical.

Additional studies were done to more fully clarify certain conditions used in these experiments: $(l)$ the effect of clotting blood in glass versus polypropylene tubes and (2) the effect of clotting blood in plastic at $0^{\circ} \mathrm{C}$ versus $37^{\circ} \mathrm{C}$. There was no difference in the effect of $\mathrm{CF}$ and normal serum using these various conditions; however, we did observe that if the clotting process had not progressed to completion, this being particularly true for the samples incubated at $0^{\circ} \mathrm{C}$, the addition of serum

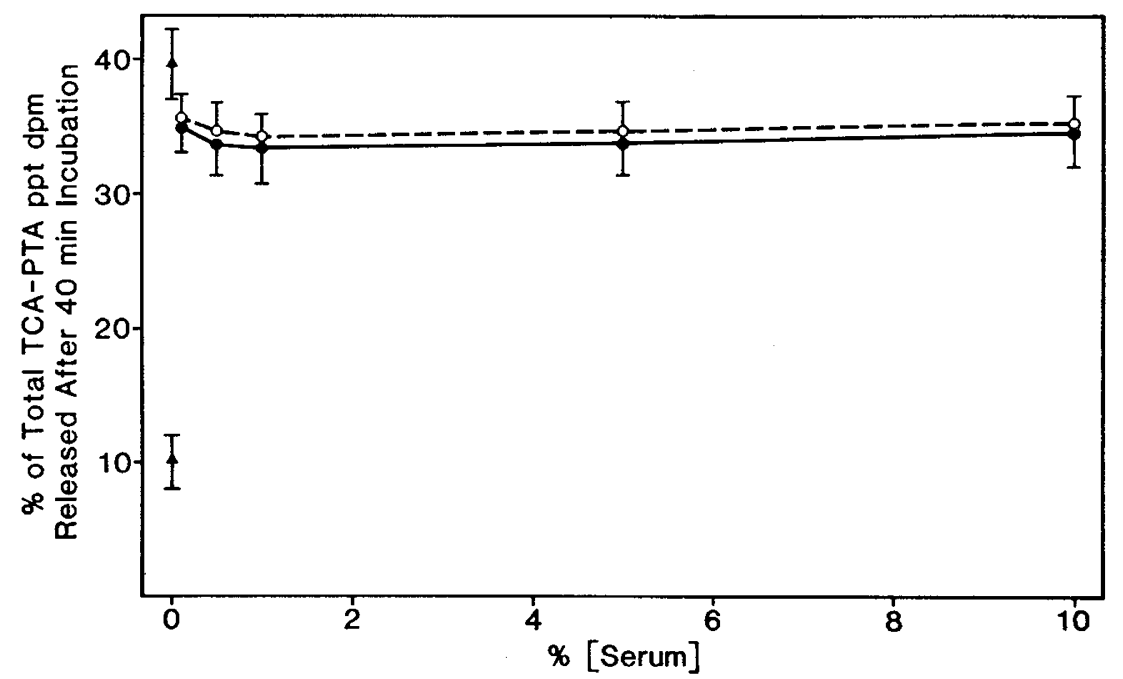

Fig. 1. Effect of increasing concentrations of $C F(O)$ and normal serum $(\bullet)$ on the secretion of $D-\left[1-{ }^{14} \mathrm{C}\right]$ glucosamine-labeled mucin in response to $40 \mathrm{~min}$ of $\beta$-adrenergic receptor stimulation using $10 \mu \mathrm{M}(-)$-isoproterenol. (A), stimulated or unstimulated cells in the absence of serum. Each value represents mean value of four separate experiments. Vertical bars represent \pm S.D. 


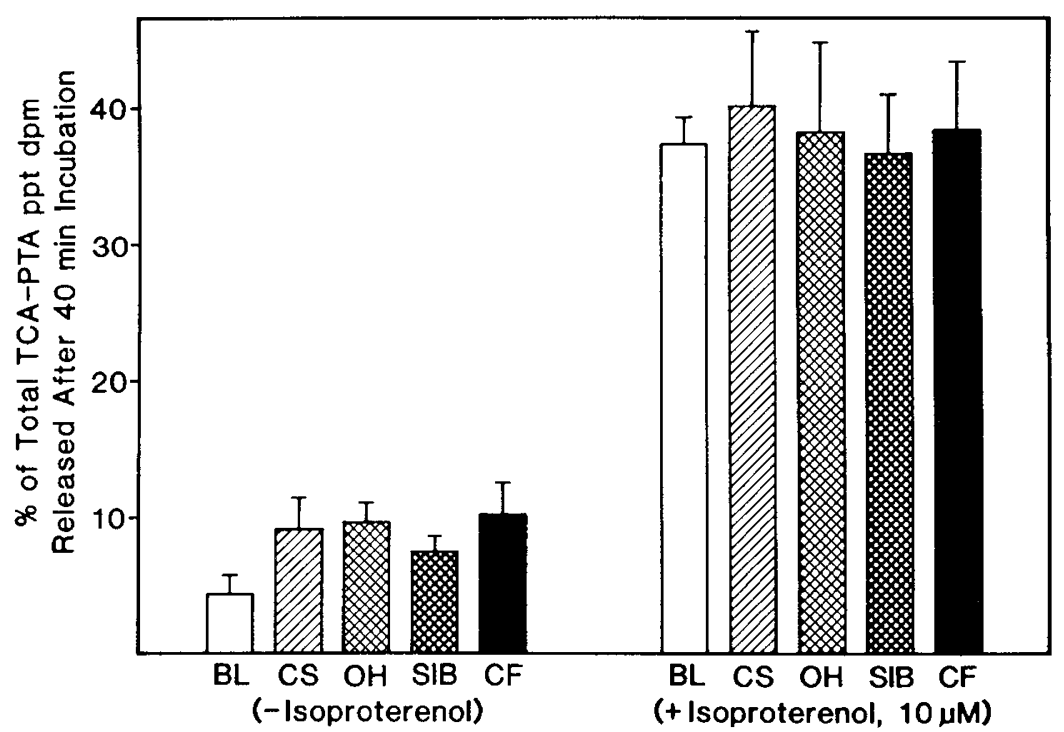

Fig. 2. Effect of serum $(5 \%)$ on the secretion of $\mathrm{D}-\left[1-{ }^{14} \mathrm{C}\right] \mathrm{glucosamine}$-labeled mucin in the absence or presence of $\beta$-adrenergic receptor stimulation. $\mathrm{BL}$, no serum added, $n=12 ; \mathrm{CS}$, control serum, $n=12 ; \mathrm{OH}$, obligatory heterozygote, $n=7 ; \mathrm{SIB}$, sibling, $n=4 ;$ and $\mathrm{CF}$, cystic fibrosis serum, $n=12$. Each value represents mean value; vertical bars represent \pm S.D. Total of six separate experiments were required to evaluate all of the samples with each sample being done in triplicate.

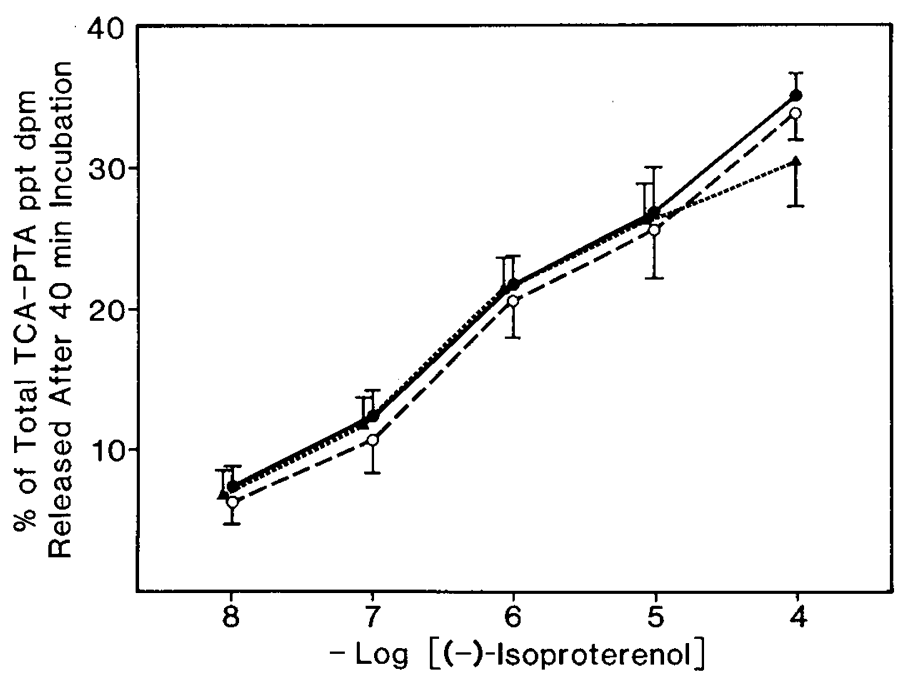

Fig. 3. Dose-response relationship for the secretion of $\mathrm{D}-\left[1-{ }^{14} \mathrm{C}\right] \mathrm{glu}-$ cosamine-labeled mucin after $\beta$-adrenergic receptor stimulation in the absence $(\boldsymbol{\Delta})$ or presence of $5 \% \mathrm{CF}$ serum $(O)$ or normal serum $(\bullet)$. Each value represents mean value of four separate experiments. Vertical bars represent \pm S.D.

(normal or CF serum) to the dispersed rat submandibular cells caused cell aggregation and eventually cell lysis. Again, no differential effect between CF serum and normal serum was observed.

\section{DISCUSSION}

Because the goal of these studies was to evaluate the possible existence of CF factors that relate to the primary genetic expression of the disease, CF subjects were selected to minimize possible secondary and tertiary effects. Viral or bacterial infection, bacterial cell metabolites, antibiotics, theophylline, etc., which are present in some CF serum, could conceivably alter mucin glycoprotein release. Patients were selected that were not under excessive medication or those patients who were on prophylactic theophylline treatment were asked to discontinue therapy for 48 $\mathrm{h}$ before sampling. All donors, including control subjects, were asked not to consume any substances containing caffeine or aspirin within $8 \mathrm{~h}$ before collection.
The dispersed rat submandibular gland preparation allows one, in a simple bioassay, to search for the presence of CF serum factors that modify acinar cell secretory function. Using this protocol we were unable to detect any differential effects of $C F$ serum on mucin secretion from dispersed rat submandibular cells. In an earlier report (14), we were also unable to detect any differential effects of $\mathrm{CF}$ serum on net $\mathrm{K}^{+}$efflux from these same cells. As with $\mathrm{K}^{+}$release $(9,12), \beta$-adrenergic receptor mediated mucin secretion is sensitive to changes in calcium metabolism but mucin secretion also involves a cyclic AMP mediated regulatory pathway $(10,11)$. Any changes observed in the extent of mucin release could reflect the action of chemical effectors upon any of several different components involved in mucin secretion: direct activation of $\beta$-adrenergic receptor-adenylate cyclase complex, general membrane function, secretion linked calcium transport, and intracellular transmission of the secretory signal, etc. Alterations in any of these parameters would cause either an inhibition or an augmentation of the observed secretory response. An example: if the CF factors did in fact increase cellular permeability to calcium, then these factors should have, in the presence of pure $\beta$-adrenergic receptor mediated stimulation, significantly increased the rate of mucin release $(10,11)$. This did not occur.

Although it is possible that the concentration of the exocrine gland active CF factors in CF serum was too low to detect using this particular bioassay system, it is very difficult to reconcile our results, the previously reported $\mathrm{K}^{+}$release studies (14) and the data described herein, with the recent report of Bogart et al. (3). Using a rat submandibular slice system in which $1 \mathrm{mM}$ ouabain was included in the medium, these investigators reported the presence of a bioactive factor in CF serum that caused a calciumdependent $\mathrm{K}^{+}$efflux from rat submandibular slices. Serum levels as low as $0.5 \%$ were able to elicit an altered response.

We have shown previously that the isolated rat submandibular cell preparation demonstrated a high sensitivity to secretagogue stimulation (9-12), which was well within the physiologic range. We have shown also that net $\mathrm{K}^{+}$efflux (9) and mucin release (10) were very sensitive to calcium entry into the cell, and changes in cellular permeability to calcium had a pronounced effect on $\mathrm{K}^{+}$release and on mucin release. Yet, using serum concentrations up to 50 times that reported by Bogart et al. (2) we were still unable to detect any differences, let alone changes which were calcium-dependent or CF serum specific. We did observe a marginal but significant enhancement of mucin release from 
unstimulated cells when these cells were in the presence of serum But again, no differences in the enhancement of mucin release were observed when the various groups were compared; i.e., normal serum, CF serum, serum from obligatory heterozygotes, or serum from CF siblings.

Recent studies using rabbit tracheal epithelium explants have shown that human serum contains bioactive substances that enhance the rate of mucous glycoprotein release and an equivalent amount of CF serum results in a further enhancement of mucous glycoprotein secretion $(2,5,6,8)$. Because we were unable to observe a mucus stimulatory effect of serum in our system, the previous reports may reflect a specific response of lung tracheal epithelium rather than a generalized serum effect on all exocrine secreting tissue.

We were unable to observe any differential effects of CF serum on the basal rate of mucin release as has been previously reported by Fleming and Sturgess (7). But, their preparation of isolated submandibular cells and the radiolabeling procedures they used to document mucin release were substantially different than ours.

We were unable to document a mucus-stimulatory substance in serum from CF patients. Nor were we able to demonstrate the presence of mucus-stimulatory substances in normal serum using dispersed rat submandibular cells.

\section{REFERENCES AND NOTES}

1. Blitzer, M. G. and Shapira, E.: A purified serum glycopeptide from controls and cystic fibrosis patients. I. Comparison of their mucociliary activity on rabbit tracheal explants. Pediatr. Res., 16:203 (1982).

2. Boat, T. F., Polony, I., and Cheng, P. W.: Mucin release from rabbit tracheal epithelium in response to sera from normal and cystic fibrosis subjects. Pediatr. Res., 16: 792 (1982).

3. Bogart, B. I., Picarelli, J., Gaerlan, P. A., and Denning, C. R.: Biological activities on cystic fibrosis serum. IV. Stimulation of the calcium mediated $\mathrm{K}^{+}$efflux from rat submandibular gland fragments. Pediatr. Res., 16: 1223 (1982).

4. Carson, S. D. and Bowman, B. H.: Cystic fibrosis. I. Fractionation of the mucociliary inhibitor from plasma. Pediatr. Res., 16: 13 (1982).

5. Conover, J. H. and Conod, E. J.: The influence of cystic fibrosis serum and calcium on secretion in the rabbit tracheal mucociliary apparatus. Biochem. Biophys. Res. Commun., 83: 1595 (1978).

6. Czegledy-Nagy, E. and Sturgess, J. M.: Cystic fibrosis: effects of serum factors on mucus secretion. Lab. Invest., 35: 588 (1976).

7. Fleming, N. and Sturgess, J. M.: Stimulation of glycoprotein secretion in dispersed rat submandibular gland acini by cystic fibrosis serum. Experimentia, 37: 139 (1981).

8. Peatfield, A. C., Hall, R. L., Richardson, P. S., and Jeffery, P. K.: The effect of serum on the secretion of radiolabeled mucous macromolecules into the lumen of the cat trachea. Am. Rev. Resp. Dis., 125: 210 (1982).

9. Quissell, D. O.: Secretory response of dispersed rat submandibular cell. 1. Potassium release. Am. J. Physiol., 238 (Cell Physiol. 7): C90 (1980).

10. Quissell, D. O. and Barzen, K. A.: Secretory response of dispersed rat submandibular cells II. Mucin secretion. Am. J. Physiol. 238 (Cell Physiol. 7): C99 (1980).

11. Quissell, D. O., Barzen, K. A., and Lafferty, J. L.: Role of calcium and cAMP in the regulation of rat submandibular mucin secretion. Am. J. Physiol., 241 (Cell Physiol. 10): C76 (1981).

12. Quissell, D. O. and Redman, R. S.: Functional characteristics of dispersed rat submandibular cells. Proc. Natl. Acad. Sci. USA, 76: 2789 (1979).

13. Taussig, L. M., Kattwinkel, J., Friedwald, W. T., and di Sant'Agnese, P. A.: A new prognostic score and clinical evaluation system for cystic fibrosis. J. Pediatr., 82: 380 (1973)

14. Seale, T. W., Flux, M., Rennert, O. M., Quissell, D. O., Barzen, K. A., and Lafferty, J. L.: Cystic fibrosis factors: Effect of serum on the secretory response of dispersed rat submandibular cells. Pediatr. Res., 14: 1398 (1980).

15. Spock, A., Heick, H. M., Cress, H., and Logan, W. S.: Abnormal serum factor in patients with cystic fibrosis of the pancreas. Pediatr. Res., 1 : 173 (1967).

16. Venipuncture of human subjects in this study was approved by Human Subject Committee, University of Colorado Health Sciences Center and was performed with informed consent of all participants.

17. Recipient of Cystic Fibrosis Research Scholar Award.

18. Requests for reprints should be addressed to: Dr. David Quissell, Department of Biochemistry, Biophysics and Genetics, University of Colorado Health Sciences Center, 4200 East Ninth Avenue, Denver, CO 80262.

19. Fellow in Pediatric Pulmonary Medicine, Department of Pediatrics, University of Colorado School of Medicine.

20. The authors thank Dr. Ernest Cotton, Dr. Frank Accurso, and Ms. Margo Pinney, R. N. for their assistance in procurement of the serum samples.

21. This research was supported by a grant from Cystic Fibrosis Foundation E630A, by the National Institutes of Health Grants DE-04778 and AM-27278, and by Pediatric Pulmonary Section, Department of Pediatrics, University of Colorado School of Medicine, Denver, CO.

22. Received for publication April 22, 1982.

23. Accepted for publication March 25, 1983. 